\title{
Antibiotic Residues in Filtered Honeys
}

\author{
Sema Ağaoğlu1 ${ }^{1, a}$, Süleyman Alemdar ${ }^{1, b}$, Nazlı Ercan ${ }^{2, c, *}$ \\ ${ }^{1}$ Department of Food Hygiene and Technology, Faculty of Veterinary, Sivas Cumhuriyet University, 58140 Sivas, Turkey \\ ${ }^{2}$ Department of Biochemistry, Faculty of Veterinary, Sivas Cumhuriyet University 58140 Sivas, Turkey \\ *Corresponding author

A R T I C L E I N F O A B S T R A C T \\ Research Article \\ In this study, tetracycline and streptomycin group antibiotic residues were investigated in packaged \\ and open sold honey. For this purpose, a total of 60 honey samples, which were 30 of each were \\ used as material. Honey samples were taken from various sales places located in Sivas province. \\ ELISA method was used for the analysis and commercial test kits were used. According to the \\ Received : 16/06/2020 \\ Accepted : 04/08/2020 \\ analysis results; tetracycline was found in $73.3 \%$ (22 samples) of the packaged honey and \\ streptomycin was found in all samples. Tetracycline and streptomycin were determined as positive \\ in open honeys were respectively $60 \%$ (18 samples) and $93.3 \%$ (28 samples). Tetracycline levels \\ were between $0.12-371.44 \mathrm{ppb}$ (mean $13.91 \pm 12.33)$ in packaged honey and 0.02-13.32 ppb (mean \\ $1.75 \pm 0.5)$ in open honeys. Streptomycin levels were 1.30-250.2 ppb (mean $25.8 \pm 10.8$ ) in \\ packaged honey and $0.19-22.71 \mathrm{ppb}$ (mean $8.21 \pm 5.2$ ) in open honeys. Antibiotic residue was not \\ Keywords: \\ Honey \\ Antibiotic \\ found in one sample of open honeys. The findings suggest that, although illegal, some medicines \\ are used in beekeeping or that bees are exposed to antibiotics that are added to the feed or water of \\ Residue \\ other animals. These findings pose a potential risk to the consumer. \\ ELISA \\ Sivas
}

\section{Introduction}

Beekeeping is an agricultural activity that brings economic aspects in the world and widely held in Turkey. According to Turkey Statistical Institute (TÜİK) data world honey production was 1,861 thousand tons and the hive presence was 91,000 (thousand units) and the yield per hive was determined as $20.4 \mathrm{~kg}$ in 2017 . In terms of assets for hive; India first (12.8 million), China second (9.2 million), Turkey third (7.8 million), Iran fourth (7.3 million) and Ethiopia fifth (6.1 million) ranks. Honey yield per hive is reported to be $60.2 \mathrm{~kg}$ in China, $56.6 \mathrm{~kg}$ in Canada, $56.3 \mathrm{~kg}$ in Portugal, $42.4 \mathrm{~kg}$ in Uruguay and 41.1 $\mathrm{kg}$ in Brazil. In the same year honey yield per colony was determined to be $14.7 \mathrm{~kg}$ in Turkey (TÜİK, 2017).

Turkey ranks at 2 nd after China in honey production. Especially the Aegean region, Eastern Black Sea and Mediterranean regions are suitable for beekeeping in terms of plant flora. According to TÜİK data; the number of beekeeping holdings was 81,108 (number), number of hives was 7,083 (thousand), honey production was 103,525 tons in 2014; the number of hives was 7,748 (thousand) and honey production was reported as 108,128 tons in 2015. The number of hives increased by $2 \%$ to 7,900 (thousand units) and honey production decreased by $2.2 \%$ to 105,727 tons in 2016. Honey production was 114,471 tons in 2017. The number of hives was 8.108.424 (units), honey production was 107.920 tons and honey yield per hive was $13.3 \mathrm{~kg}$ in 2018 . Honey consumption is over $1 \mathrm{~kg}$ per person in our country. This amount is $0.05 \mathrm{~kg}$ in the world, $0.7 \mathrm{~kg}$ in EU countries, $0.2 \mathrm{~kg}$ in China, $0.9 \mathrm{~kg}$ in New Zealand and $0.6 \mathrm{~kg}$ in the USA (Anonim, 2019).

Honey "Is a natural product as plant nectars, secretions of living parts of plants or secretions of plant-sucking insects living on living parts of plants by combining them with their own substances after being collected by honeybees (Apis mellifera L.) and maturing by storing in honeycomb defined in the Turkish Food Codex (TGK, 2012).

Definition of honey in Turkish Standards (TS, 2002); The collection of nectars in the flowers of the plants or the sweet parts secreted by the living parts of the plants and some monogamous insects by their honeybees (Apis mellifera L.), a sweet product of dark consistency which occurs as a result of maturation and storage in the honeycomb eyes of their bodies.

According to resources of honey, flower honey (nectar honey), secretion honey (pine honey), poison honey (crazy 
honey), artificial honey, feeding honey and express honey, according to production and market type; honeycomb, strained honey, honeycomb filtered honey, extra honey, press honey and filtered honey; according to color, water white, extra white, extra light amber and dark color classified. Depending on the plant pigments it contains, the colour of honey varies from water white to dark amber (TGK, 2012).

The plant flora and climate of the production region have an impact on the composition of honey. Honey generally contains $80 \%$ sugar and $17 \%$ water. The remaining $3 \%$ consists of minerals, vitamins, amino acids, colorants and enzymes. Honey is not suitable for microbial growth due to its high sugar content, low water activity and acidity (pH 3-4). Phenolic compounds in its composition (flavonoids, phenolic acid) give to honey antioxidant properties (TGK, 2012).

Honey is a natural food that can be consumed in any age group, except for those with diabetes and allergies and children under one-year-old. Food industry, pharmaceutical and cosmetic, as well as for the treatment of certain diseases (apitherapy) has a wide range of uses. Beside honey the bee products such as royal jelly, propolis, pollen and beeswax are also important for health and nutrition (Özmen and Alkın 2006; Anonim, 2014a; Ömür, 2015).

Drugs used against firstly varroa and juvenile rot, bee diseases and parasites lead to significant losses in beekeeping. Unnecessary or unconscious use of these drugs poses a potential risk to consumer health and economy. Antibiotic residues in foods cause allergic reactions, anaphylactic shock, nervous disorders, impaired intestinal flora, and resistance to bacteria in susceptible individuals. It has also been reported to have carcinogenic and teratogenic effects (Nisha, 2008; Kaftanoğlu, 2000; Al-Waili et al, 2012; Tayar and Yarsan, 2014; Kaya, 2018).

The tetracycline group of antibiotics (tetracycline, oxytetracycline, clortetracycline, doxycycline) are effective on Gram (+) and Gram (-) aerobic and anaerobic bacterias. Tetracycline's are broad-spectrum antibiotics. They produce bacteriostatic effects which inhibit bacterial cell protein synthesis. They are not suitable for use in pregnant women and children under 8 years of age because this group of antibiotics causes permanent discoloration of the teeth. Streptomycin group of antibiotics are classified into aminoglycosides. Antibiotics in this group are effective on Gram (-) bacteria. They show bactericidal effect by inhibiting protein synthesis (Kaya, 2000; Yarsan, 2018).

Sivas ranks at 6 th after Ordu, Muğla, Adana, Aydın and Mersin provinces in honey production. The region is rich in plant flora. Divriği, Zara and Koyulhisar are the districts where intensive beekeeping is done. Honey production in Sivas province was 2,908 tons in 2010. This amount was determined as 3,039 tons in 2014. The number of hives was 219,942 (units), honey production was 2,861 tons in 2016; the number of hives was 215,878 (units) and the production of honey was 3,715 tons in 2017. There are 3,427 enterprises related to beekeeping in Sivas (Anonim, 2014b; Arslan, 2016; TÜİK, 2017).

In this study, branded and open 60 strained honey samples taken from various outlets in Sivas province were examined for tetracycline and streptomycin group antibiotic residues. The data obtained were evaluated in terms of food safety and public health considering the standard values and public health considering the standard values.

\section{Materials and Methods}

In this study, a total of 60 strained honey samples, 30 of which were packaged and branded and 30 of which were open, were used as material. Honey samples were collected periodically from the sales places (market, grocery, street market, wholesaler) in Sivas province in March-May 2018 period. Disposable sterile falcon tubes $(50 \mathrm{ml})$ were used for sampling. Packed honeys were selected from different brands and purchased in their original form. Samples were brought to the laboratory of the Department of Biochemistry, Faculty of Veterinary Medicine, Sivas Cumhuriyet University and analysed on the same day. Honey samples were kept in a cool environment during this process.

Tetracycline and streptomycin group antibiotic levels in honey samples were determined by Enzyme Linked Immunosorbent Assay (ELISA). The test kits which are Sinogeneclon Streptomycin ELISA (SG-4011) and Sinogeneclon Tetracycline ELISA (SG-4021) were used in the analyses. Analyses were performed according to the kit procedures. Descriptive statistics of tetracycline and streptomycin levels were determined in SPSS 22.00 package program (SPSS, 2014).

\section{Results}

The statistical values and percentage (\%) distribution of tetracycline and streptomycin levels detected in packaged and open sold filter honeys are given in Table 3-6.

According to the analysis results; $73.3 \%$ (22 samples) of tetracycline and 100\% (30 samples) of streptomycin were determined in packaged honeys. Ratios of tetracycline and streptomycin were 60\% (18 samples) and 93.3\% (28 samples) respectively in open honey samples. Tetracycline level was determined between 0.12-371.44 ppb (mean 13.91 \pm 12.33 ) in packaged honey and 0.02$13.32 \mathrm{ppb}$ (mean $1.75 \pm 0.5$ ) in open ones. Streptomycin levels were found to be 1.30-250.2 ppb (mean 25.8 \pm 10.8 ) in packaged honey and 0.19-22.71 ppb (mean $8.21 \pm 5.2$ ) in the open ones. Antibiotic residue was not found in only one sample of open honeys.

\section{Discussion}

In this study, antibiotic residues and levels of tetracycline and streptomycin group were investigated in packaged and open-sold filtered honeys. A total of 60 honey samples, 30 piece of each variety, were used as material. Samples were taken from sales places located in Sivas province. ELISA method was used in the analysis via commercial test kits.

According to the analysis findings; residues of tetracycline $22(73.3 \%)$ and $100 \%$ (30 samples) of streptomycin group antibiotic were detected in packaged honey. Levels of tetracycline and streptomycin were determined between 0.12-371.44 ppb (mean 13.91 \pm 12.33 ) and 1.30-250.2 ppb (mean $25.8 \pm 10.8$ ) respectively in these sample. Samples of $18(60 \%)$ were positive for tetracycline and samples of $28(93.3 \%)$ were positive for 
streptomycin residue in open honeys. Residue levels were between $0.02-13.32 \mathrm{ppb}$ (mean $1.75 \pm 0.5$ ) and 0.19-22.71 ppb (mean $8.21 \pm 5.2$ ) in the same order. Tetracycline and streptomycin residue were not found in one sample of open honeys (Table 3-6).

The studies were conducted level of tetracycline $<0.04$ $42 \mathrm{ppb}$ and level of streptomycin $<10 \mathrm{ppb}$ in honey in Turkey of different regions in different years (Sunay, 2006; Gül, 2008; Seğmenoğlu, 2013; Derebaşı et al., 2014; Özkan et al., 2015; Korkmaz et al., 2017; Bağc1, 2019). Tetracycline content of examined honey samples was 3.3$58.3 \%$; streptomycin ratio was determined between 5$52.5 \%$ (Table 1).

In this study, levels of tetracycline and streptomycin and positivity rates were found higher in the packaged and open filtered honeys than the results of these researchers. The determined values do not coincide with the findings of the researchers (Güneş et al., 2009; Polat, 2011; Kutlu et al., 2017; Saygill, 2017) who reported that tetracycline and streptomycin residues were not found in honey. Differences between research results can be explained by the fact that honeys of different origins and origin belong to different regions the number of samples and method differences.

When the studies conducted in other countries are examined; Sarıdaki-Papakonstadinou et al. (2006) tetracycline levels in honey samples of different properties 0.018-0.057 mg/kg (Greece); Diserens (2007) $0.5 \mathrm{~g} / \mathrm{kg}$ (Switzerland); Bonvehi and Gutierrez (2008) 15-920 $\mu \mathrm{g} / \mathrm{kg}$ (Spain); Taokaenchan and Sangrichan (2010) 7.18-14.06 $\mathrm{mg} / \mathrm{kg}$ (Thailand); Zai et al. (2013) $3.67 \mu \mathrm{g} / \mathrm{ml}$ (Pakistan); Berehoiu et al. (2013) 13,21-18,33 ppb (Romania); Mahmoudi et al. (2014b) 0.2-6.2 $\mu \mathrm{g} / \mathrm{kg}$ (Iran); Saleh et al. (2016) found that they were $2,330 \mu \mathrm{g} / \mathrm{kg}$ (Yemen). Tetracycline rates in honey samples were determined between 4-100\% (Reybroeck, 2003, SarıdakiPapakonstadinou et al., 2006; Bonvehi and Gutierrez, 2008; Baggio et al., 2009; Berehoiu et al., 2013; Mahmoudi et al., 2014b). (Table 2).

Table1. Antibiotic residue levels in different types of honey in studies in Turkey

\begin{tabular}{|c|c|c|c|c|c|}
\hline Province & $\mathrm{n}$ & Antibiotic & $\mathrm{n}_{1}(\%)$ & Residue level & Reference \\
\hline Different provinces & $\begin{array}{c}1714 \\
1421 \\
91 \\
\end{array}$ & $\begin{array}{l}\text { Sulphamethazine } \\
\text { Tetracycline } \\
\text { Streptomycin }\end{array}$ & $\begin{array}{c}\% 10 \\
\% 15 \\
\% 5-10 \\
\end{array}$ & $\begin{array}{l}11 \mathrm{ppb} \\
<13.65 \mathrm{ppb} \\
<10 \mathrm{ppb}\end{array}$ & Sunay (2006) \\
\hline İstanbul & 100 & Naphthalene & 1 & $1.13 \mu \mathrm{g} / \mathrm{kg}$ & $\begin{array}{l}\text { Beyoğlu and Omurtag } \\
\text { (2007) }\end{array}$ \\
\hline Ege region & 103 & Sulfonamide & $\% 23$ & & Uludağ $(2008)$ \\
\hline İstanbul & 610 & $\begin{array}{l}\text { Sulfonamide } \\
\text { Tetracycline } \\
\text { Streptomycin }\end{array}$ & $\begin{array}{l}\% 29,5 \\
\% 3,3 \\
\% 11,9\end{array}$ & & Gül (2008) \\
\hline Güney Marmara & 50 & Erythromycin & $4(\% 8)$ & $50-1776 \mathrm{ng} / \mathrm{kg}$ & Güneş et al. (2008) \\
\hline Güney Marmara & 50 & $\begin{array}{l}\text { Oxytetracycline } \\
\text { Sulfanamid }\end{array}$ & n.d. & n.d. & Güneş et al. (2009) \\
\hline İzmir & 10 & $\begin{array}{l}\text { Sulfadiazine } \\
\text { Sulphamethazine }\end{array}$ & 10 & $\begin{array}{c}0.017-0.643 \\
\text { ppm } \\
0.006-0.162 \\
\text { ppm } \\
\end{array}$ & Özgenç (2011) \\
\hline İzmir & 536 & Sulfanamid & 126 & & Erdoğdu et al. (2011) \\
\hline Güney Marmara & & $\begin{array}{l}\text { Chloramphenicol } \\
\text { Sulphonamide } \\
\text { Tetracycline }\end{array}$ & & n.d. & Polat (2011) \\
\hline Different provinces & 56 & Streptomycin & 4 & & Seğmenoğlu (2013) \\
\hline Ankara & 120 & Naphthalene & $11(\% 9,16)$ & $1.1-6.2 \mathrm{ppb}$ & Şireli (2013) \\
\hline $\begin{array}{l}\text { Different provinces } \\
\text { and counties }\end{array}$ & 98 & Chloramphenicol & 7 & $0-1.27 \mathrm{ppb}$ & Toptanc1 (2013) \\
\hline Karadeniz region & 209 & $\begin{array}{l}\text { Streptomycin } \\
\text { Sulfonamide } \\
\text { Tetracycline } \\
\end{array}$ & $\begin{array}{c}13 \\
59 \\
7 \\
\end{array}$ & & Derebaşı et al. (2014) \\
\hline Ardahan ve ilçeleri & 180 & $\begin{array}{l}\text { Streptomycin } \\
\text { Sulfanamid }\end{array}$ & $\begin{array}{l}68(\% 37,7) \\
94(\% 52,2)\end{array}$ & $\begin{array}{l}1.79 \mathrm{ppm} \\
1.19 \mathrm{ppm}\end{array}$ & Özkan et al. (2015) \\
\hline Bitlis & 20 & $\begin{array}{l}\text { Tetracycline } \\
\text { Sulfanamid }\end{array}$ & & n.d. & Kutlu et al. (2017) \\
\hline Ege region & 59 & $\begin{array}{l}\text { Tetracycline } \\
\text { Sulfanamid }\end{array}$ & $\begin{array}{c}35(\% 35) \\
31\end{array}$ & $\begin{array}{l}\text { 6-42 ppb } \\
3-32 \mathrm{ppb}\end{array}$ & Korkmaz et al. (2017) \\
\hline Kirklareli & 57 & $\begin{array}{l}\text { Streptomycin } \\
\text { Chloramphenicol } \\
\text { Tetracycline }\end{array}$ & & n.d. & Sayg1lı (2017) \\
\hline Different provinces & 90 & Naphthalene & 1 & $115.23 \mathrm{ppb}$ & Gölge et al. (2017) \\
\hline Muğla and counties & 84 & $\begin{array}{l}\text { Tetracycline } \\
\text { Sulphamethazine }\end{array}$ & $\begin{array}{c}49(\% 58,3) \\
84(\% 10)\end{array}$ & $\begin{array}{c}<0.04-0.391 \mathrm{ppb} \\
<10 \mathrm{ppb}\end{array}$ & Bağcı (2019) \\
\hline Antalya & 30 & Naphthalene & 3 & $3.0-8.9 \mu \mathrm{g} / \mathrm{kg}$ & Çakar and Gürel (2019) \\
\hline
\end{tabular}


Table 2. Antibiotic residue levels in different types of honey in studies conducted in various countries

\begin{tabular}{|c|c|c|c|c|c|}
\hline Country & $\mathrm{n}$ & Antibiotic & $\mathrm{n}_{1}(\%)$ & Residue Level & Reference \\
\hline Belgium & $\begin{array}{c}108 \\
98 \\
248 \\
72 \\
\end{array}$ & $\begin{array}{l}\text { Streptomycin } \\
\text { Tetracycline } \\
\text { Streptomycin } \\
\text { Tetracycline }\end{array}$ & $\begin{array}{l}51(\% 47) \\
29(\% 30) \\
4(\% 1,6) \\
2(\% 2,8)\end{array}$ & & Reybroeck (2003) \\
\hline Holland & 186 & Dihydrostreptomycin & $\% 26$ & & Bruijnsvoort et al. (2004) \\
\hline Switzerland & 75 & Chloramphenicol & $13(\% 17)$ & $0,4-0,6 \mu \mathrm{g} / \mathrm{kg}$ & Ortelli et al. (2004) \\
\hline Greece & 251 & $\begin{array}{l}\text { Tetracycline } \\
\text { Oxytetracycline } \\
\text { Doxycycline } \\
\text { Chlortetracycline }\end{array}$ & $\begin{array}{l}\% 97 \\
\% 94 \\
\% 90 \\
\% 96\end{array}$ & $\begin{array}{l}0,018-0,057 \mathrm{mg} / \mathrm{kg} \\
0,023-0,335 \mathrm{mg} / \mathrm{kg} \\
0,018-0,190 \mathrm{mg} / \mathrm{kg} \\
0,013-0,393 \mathrm{mg} / \mathrm{kg}\end{array}$ & $\begin{array}{c}\text { Sarıdaki-Papakonstadinou et } \\
\text { al. (2006) }\end{array}$ \\
\hline Switzerland & 3855 & $\begin{array}{l}\text { Streptomycin } \\
\text { Sulfanamid } \\
\text { Tetracycline } \\
\text { Chloramphenicol }\end{array}$ & & $\begin{array}{c}3,0-10,82 \mathrm{~g} / \mathrm{kg} \\
5,0 \mathrm{~g} / \mathrm{kg} \\
5,0 \mathrm{~g} / \mathrm{kg} \\
0,1-169 \mathrm{~g} / \mathrm{kg}\end{array}$ & Diserens (2007) \\
\hline Spain & 567 & $\begin{array}{l}\text { Sulfonamide } \\
\text { Tetracycline } \\
\text { Chloramphenicol }\end{array}$ & $\begin{array}{l}68(\% 12) \\
24(\% 4)\end{array}$ & $\begin{array}{l}15-920 \mu \mathrm{g} / \mathrm{kg} \\
\text { n.d. }\end{array}$ & $\begin{array}{l}\text { Bonvehi and Gutierrez } \\
\qquad(2008)\end{array}$ \\
\hline Italy & 4084 & $\begin{array}{l}\text { Sulfonamide } \\
\text { Tetracycline } \\
\text { Streptomycin } \\
\text { Chloramphenicol } \\
\text { Tylosin }\end{array}$ & $\begin{array}{l}\% 10,6 \\
\% 4,2 \\
\% 2,8 \\
\% 1,8 \\
\% 5,2\end{array}$ & & Baggio et al. (2009) \\
\hline Spain & 16 & $\begin{array}{l}\text { Erythromycin } \\
\text { Sarafloksasin } \\
\text { Tylosin } \\
\text { Sulfadimidine } \\
\text { Sulfacloropridosine }\end{array}$ & $\begin{array}{l}3 \\
1\end{array}$ & $\begin{array}{c}8,6 \mu \mathrm{g} / \mathrm{kg} \\
14,6 \mu \mathrm{g} / \mathrm{kg} \\
3,2 \mu \mathrm{g} / \mathrm{kg} \\
\text { iz mikt. }\end{array}$ & Vidal et al. (2009) \\
\hline Thailand & 6 & $\begin{array}{l}\text { Oxytetracycline } \\
\text { Tetracycline } \\
\text { Chlortetracycline }\end{array}$ & $\begin{array}{l}4 \\
2\end{array}$ & $\begin{array}{c}60,15-106,9 \mathrm{mg} / \mathrm{kg} \\
7,18-14,06 \mathrm{mg} / \mathrm{kg} \\
\text { n.d. }\end{array}$ & $\begin{array}{l}\text { Taokaenchan and } \\
\text { Sangrichan (2010) }\end{array}$ \\
\hline India & 12 & Oxytetracycline & $6(\% 50)$ & $27,1-250,4 \mu \mathrm{g} / \mathrm{kg}$ & Johnson and Jadon (2010) \\
\hline $\begin{array}{l}\text { Bosnia } \\
\text { Herzegovina }\end{array}$ & 46 & & - & n.d. & Mujic et al. (2011) \\
\hline Pakistan & 100 & $\begin{array}{l}\text { Streptomycin } \\
\text { Tetracycline } \\
\text { Streptomycin } \\
\text { Tetracycline }\end{array}$ & 18 & $\begin{array}{c}1,42 \mu \mathrm{g} / \mathrm{mL} \\
3,67 \mu \mathrm{g} / \mathrm{mL} \\
12,02 \mu \mathrm{g} / \mathrm{mL} \\
16,31 \mu \mathrm{g} / \mathrm{mL} \\
\end{array}$ & Zai et al. (2013) \\
\hline Romania & 18 & $\begin{array}{l}\text { Streptomycin } \\
\text { Tetracycline } \\
\text { Erythromycin }\end{array}$ & $18(\% 100)$ & $\begin{array}{c}42,77-51,49 \mathrm{ppb} \\
13,21-18,33 \mathrm{ppb} \\
0,06-0,27 \mathrm{ppb}\end{array}$ & Berehoiu et al. (2013) \\
\hline Iran & 145 & Oxytetracycline & $34(\% 23,4)$ & $5,32-369,1 \mu \mathrm{g} / \mathrm{kg}$ & Mahmoudi et al. (2014a) \\
\hline Iran & 135 & $\begin{array}{l}\text { Tetracycline } \\
\text { Gentamycin }\end{array}$ & $\begin{array}{l}19(\% 14) \\
25(\% 17) \\
\end{array}$ & $\begin{array}{c}0,2-6,2 \mu \mathrm{g} / \mathrm{kg} \\
0,6-72,1 \mu \mathrm{g} / \mathrm{kg} \\
\end{array}$ & Mahmoudi et al. (2014b) \\
\hline Algeria & 36 & $\begin{array}{l}\text { Oxytetracycline } \\
\text { Tetracycline } \\
\text { Streptomycin }\end{array}$ & 2 & $\begin{array}{l}0,03 \mathrm{ppb} \\
\text { n.d. } \\
\text { n.d. }\end{array}$ & Draiaia et al. (2015) \\
\hline Serbia & 193 & & $5(\% 2,59)$ & & Apic et al. (2015) \\
\hline India & 42 & Oxytetracycline & $42(\% 100)$ & $0,05-0,17 \mu \mathrm{g} / \mathrm{kg}$ & Rao et al. (2015) \\
\hline Italy & 74 & Sulfanamid & $9(\% 12)$ & $2 \mu \mathrm{g} / \mathrm{kg}$ & Galarini et al. (2015) \\
\hline Pakistan & 100 & $\begin{array}{l}\text { Penicillin } \\
\text { Streptomycin } \\
\text { Oxytetracycline }\end{array}$ & $\begin{array}{l}5(\% 5) \\
6(\% 6) \\
7(\% 7) \\
\end{array}$ & $\begin{array}{l}1,76-4,86 \mathrm{mg} / \mathrm{kg} \\
1,12-6,65 \mathrm{mg} / \mathrm{kg} \\
1,12-6,42 \mathrm{mg} / \mathrm{kg}\end{array}$ & Rahman (2016) \\
\hline Yemen & 16 & $\begin{array}{l}\text { Oxytetracycline } \\
\text { Tetracycline } \\
\text { Oxytetracycline } \\
\text { Tetracycline }\end{array}$ & & $\begin{array}{c}3,430-13,800 \mu \mathrm{g} / \mathrm{kg} \\
2,330 \mu \mathrm{g} / \mathrm{kg} \\
7,140 \mu \mathrm{g} / \mathrm{kg} \\
2,850 \mu \mathrm{g} / \mathrm{kg} \\
\end{array}$ & Saleh et al. (2016) \\
\hline India & 150 & $\begin{array}{l}\text { Oxytetracycline } \\
\text { Erythromycin } \\
\text { Chloramphenicol }\end{array}$ & $\begin{array}{l}\% 15,3 \\
\% 5,3\end{array}$ & $\begin{array}{l}9-69 \mathrm{ng} / \mathrm{g} \\
78,8 \mathrm{ng} / \mathrm{g} \\
\text { n.d. }\end{array}$ & Kumar et al. (2019) \\
\hline
\end{tabular}


Table 3. The level of tetracycline (ppb) and percentage (\%) of distribution in packaged honey samples

\begin{tabular}{c|ccccc}
\hline Tetracycline & $\mathrm{n}$ & $\%$ & Min. & Max. & Mean \pm SE \\
\hline 0 & 8 & $\% 26.7$ & 0 & 0 & 0 \\
$0-0.05$ & - & - & - & - & 0.12 \\
$0.05-0.15$ & 1 & $\% 3.3$ & 0.12 & 0.18 & 0.12 \\
$0.15-0.45$ & 1 & $\% 3.3$ & 0.18 & 1.24 & $1.002 \pm 0.12$ \\
$0.45-1.35$ & 3 & $\% 10$ & 0.85 & 3.79 & $2.41 \pm 0.19$ \\
$1.35-4.05$ & 15 & $\% 50$ & 1.51 & 371.44 & $188.92 \pm 182.51$ \\
$4.05>$ & 2 & $\% 6.7$ & 6.4 & 371.44 & $13.91 \pm 12.33$ \\
\hline Total & 30 & $\% 100$ & 0.12 & &
\end{tabular}

Table 4. The level of tetracycline (ppb) and percentage (\%) of distribution in open honey samples

\begin{tabular}{|c|c|c|c|c|c|}
\hline Tetracycline & $\mathrm{n}$ & $\%$ & Min. & Max. & Mean \pm SE \\
\hline 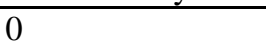 & 12 & $\% 40$ & - & - & - \\
\hline $0-0.05$ & 2 & $\% 6.7$ & 0.02 & 0.04 & $0.03 \pm 0.007$ \\
\hline $0.05-0.15$ & - & - & - & - & - \\
\hline $0.15-0.45$ & 2 & $\% 6.7$ & 0.23 & 0.44 & $0.33 \pm 0.1$ \\
\hline $0.45-1.35$ & 2 & $\% 6.7$ & 0.94 & 0.96 & $0.94 \pm 0.01$ \\
\hline $1.35-4.05$ & 8 & $\% 26.7$ & 1.52 & 3.46 & $2.35 \pm 0.2$ \\
\hline $4.05>$ & 4 & $\% 13.3$ & 5.01 & 13.32 & $7.80 \pm 1.9$ \\
\hline Total & 30 & $\% 100$ & 0.02 & 13.32 & $1.75 \pm 0.5$ \\
\hline
\end{tabular}

Table 5. The level of streptomycin (ppb) and percentage (\%) of distribution in packaged honey samples

\begin{tabular}{c|ccccc}
\hline Streptomycin & $\mathrm{n}$ & $\%$ & Min. & Max. & Mean \pm SE \\
\hline $0-0.1$ & - & - & - & - & - \\
$0.1-0.3$ & - & - & - & - & - \\
$0.3-0.9$ & - & - & - & - & $1.75 \pm 0.2$ \\
$0.9-2.7$ & 3 & $\% 10$ & 1.30 & 7.09 & $7.05 \pm 0.2$ \\
$2.7-8.1$ & 6 & $\% 20$ & 6.35 & 250.2 & $34.59 \pm 15.1$ \\
$8.1>$ & 21 & $\% 70$ & 8.73 & 250.2 & $25.8 \pm 10.8$ \\
\hline Total & 30 & $\% 100$ & 1.30 & & \\
\hline
\end{tabular}

Table 6. The level of streptomycin level (ppb) and percentage (\%) of distribution in open honey samples

\begin{tabular}{c|ccccc}
\hline Streptomycin & $\mathrm{n}$ & $\%$ & Min. & Max. & Mean \pm SE \\
\hline 0 & 2 & $\% 6.7$ & - & - & - \\
$0-0.1$ & - & - & - & - & 0.19 \\
$0.1-0.3$ & 1 & $\% 3.3$ & 0.19 & - & - \\
$0.3-0.9$ & - & - & - & 2.66 & 2.66 \\
$0.9-2.7$ & 1 & $\% 3.3$ & 2.66 & 7.9 & $5.43 \pm 1.46$ \\
$2.7-8.1$ & 12 & $\% 40$ & 3.63 & 22.71 & $12.74 \pm 3.69$ \\
$8.1>$ & 14 & $\% 46.7$ & 8.99 & 22.71 & $8.21 \pm 5.2$ \\
\hline Total & 30 & $\% 100$ & 0.19 & \\
\hline
\end{tabular}

In this study, although the levels of tetracycline detected in the filtered honey were lower than the results of some researchers (Diserens, 2007; Taokaenchan and Sangrichan, 2010; Zai et al., 2013; Saleh et al., 2016), were higher than some researchers (Sarıdaki-Papakonstadinou et al., 2006; Bonvehi and Gutierrez, 2008; Berehoiu et al., 2013; Mahmoudi et al., 2014b).

The level of streptomycin in honey examined by Diserens (2007) 3.0-10.82 g/kg, Zai et al. (2013) 1.42$12.02 \mu \mathrm{g} / \mathrm{g}$, Berehoiu et al. (2013) 42.77-51.49 ppb, Rahman (2016) found that between $1.12-6.65 \mathrm{mg} / \mathrm{kg}$. The rate of streptomycin in honey was determined to be between 1.6-100\% in studies (Reybroeck, 2003; Berehoiu et al., 2013; Rahman, 2016). In contrast to these studies, some researchers (Draiaia et al., 2015) reported that there were no residues of tetracycline and streptomycin in honey (Table 2).
In this study, streptomycin levels detected in strained honeys were found to be lower than those of some researchers (Diserens, 2007; Zai et al., 2013) and higher than the results of some studies (Berehoiu et al., 2013, Rahman, 2016). The determined values do not correlate with the findings of the researchers (Draiaia et al., 2015) who reported that they did not detect tetracycline and streptomycin in honey. The levels of tetracycline and streptomycin detected in honey samples were lower than those reported in these studies.

The European Union (EU) does not allow the use of medicines in beekeeping except for some antivarroa medicines. Maximum residue limits (MRLs) specifies for approved drugs only at the standard. MRL was not given for tetracycline and streptomycin group antibiotics. The residue level is limited to $10 \mathrm{ppb}$ for drugs that do not specify MRL if honey is exported from other countries. However, in some countries (Switzerland, United 
Kingdom, Belgium, USA, Canada, Australia, India), a limit value (0.01-0.05 $\mathrm{mg} / \mathrm{kg}$ ) was defined as "action limit" for each antibiotic group (EU, 2010).

Honey relevant legislation for Turkey prepared in line with the EU is given in "Turkish Food Codex Honey Notification (TGK, 2012)". The criteria stated in the "Turkish Food Codex on Classification of Pharmacologically Active Substances in Animal Foods and Maximum Residue Limits Regulation (TGK, 2017) are taken into consideration for veterinary drug residues in honey and other bee products. The regulation does not provide MRL for tetracycline and streptomycin antibiotics in honey.

When the research findings are examined; one sample of packaged honey tetracycline (371.44 ppb), streptomycin levels in 2 samples (250.20 ppb and $236.20 \mathrm{ppb})$ were higher than the values determined in other samples. Tetracycline was detected in one sample, streptomycin in 17 samples in packaged honey; tetracycline level was determined in one sample and streptomycin level was determined above $10 \mathrm{ppb}$ in 10 samples in open honey. Two in terms of tetracycline and 27 samples in terms of streptomycin residue strains of analysed honey samples did not comply with the limit values (10 ppb) reported by EU. Antimicrobial residue was not detected in only one sample from the examined filter honeys (Table 3-6).

\section{Conclusion}

The findings suggest that, although illegal, some medicines are used in beekeeping or that bees are exposed to antibiotics that are added to the feed or water of other animals. In this study, the residue level was found to be over $10 \mathrm{ppb}$ in almost half of the samples examined. Streptomycin levels were generally higher in the same sample except for a few samples. In addition, the residual level and positivity rate of packaged honey is higher. These findings pose a potential risk to the consumer. In this context, it would be beneficial to take the following measures.

- New legislation on honey should be introduced.

- Those interested in beekeeping should do this work consciously.

- Certified manufacturing must be mandatory.

- Drug sales should be controlled.

- Legal audits should be made more frequent by the competent authorities.

- Necessary sanctions should be applied when residues are detected above the tolerance level.

\section{Acknowledgements}

This work is supported by the Scientific Research Project Fund of Sivas Cumhuriyet University under the project number 'V-075'.

\section{References}

Al-Waili N, Salom K, Al-Ghamdi A, Ansari MJ. 2012. Antibiotic, pesticide and microbial contaminants of honey: human health hazards. The Scientific World Journal, DOI: https://doi.org/10.1100/2012/930849
Anonim 2014a. Arıcılık ve Bal Raporu. Ünye Ticaret Borsası, Kasım 2014, Ordu. http://www.bal-mer.com/Files/files/dokumanlar /aricilik-ve-bal-raporu---unye-ticaret-borsasi/Ar\%C4\%B1c\%C4 \%B11\%C4\%B1k\%20ve\%20Bal\%20Raporu\%20-\%20\%C3\%9 Cnye\%20Ticaret\%20Borsas\%C4\%B1.pdf, [Accessed: 10.10.2019]

Anonim 2014b. Sivas Tarım Hayvancılık ve Gida Sektörel Çalışma Grubu Raporu. Tarım İl Müdürlüğü, Sivas, Türkiye.

Anonim 2019. Haygem. Tarım ve Orman Bakanlığı Hayvancılık Genel Müdürlüğü. Ocak 2019, Ankara, Türkiye. http://www.etb.org.tr/media/raporlar/HAYGEM\%20\%20Ocak\%202019.pdf, [Accessed: 10.10.2019]

Apic J, Ljubojevic D, Prica N, Jaksic S, Ratajac R, Babic J, Zivkov-Balos M. 2015. Antibiotic residues in honey samples collected within one year period in AP Vojvodina, Serbia. The Serbian Journal of Agricultural Sciences, 64(3-4): 261266.

Arslan E. 2016. Sivas İli Arı Yetiştiriciliğinin Genel Yapısı ve Arıcılık Faaliyetleri. Yüksek Lisans Tezi, Fırat Üniversitesi Sağlık Bilimleri Enstitüsü, Elazığ, Türkiye.

Baggio A, Gallina A, Benetti C, Mutinelli F. 2009. Residues of antibacterial drugs in honey from the Italian market. Food Additives and Contaminants: Part B, 2(1): 52-58. DOI: https://doi.org/10.1080/02652030902897721

Bağc1 H. 2019. Muğla Bölgesinde Üretilen Ballarda Antibiyotik Kalıntılarının Araştırılması. Yüksek Lisans Tezi, Afyon Kocatepe Üniversitesi Sağlık Bilimleri Enstitüsü, Afyonkarahisar, Türkiye.

Berehoiu RT, Visovan DM, Popa CN. 2013. Study on the presence of antibiotic residues in honey intended for public consumption. Scientific Papers Series Management, Economic Engineering in Agriculture and Rural Development, 13(3): 305-308.

Beyoğlu D, Omurtag GZ. 2007. Occurrence of naphthalene in honey consumed in Turkey as determined by high-pressure liquid chromatography. Journal of Food Protection, 70(7): 1735-1738. DOI: https://doi.org/10.4315/0362-028X-70.7.1735

Bonvehi JS, Gutierrez AL. 2008. Residues of antibiotics and sulfonamides in honeys from Basque Country (NE Spain). Journal of the Science of Food and Agriculture, 89: 63-72. DOI: https://doi.org/10.1002/jsfa.3411

Bruijnsvoort MV, Ottink SJ, Jonker KM, Boer E. 2004. Determination of streptomycin and dihydrostreptomycin in milk and honey by liquid chromatography with tandem mass spectrometry. Journal of Chromatography A, 1058(1-2): 137142. DOI: https://doi.org/10.1016/j.chroma.2004.07.101

Çakar E, Gürel F. 2019. Süzme ve petekli balların pestisit, naftalin ve antibiyotik kalıntıları bakımından karşılaştırılması. Mediterranean Agricultural Sciences, 32(3): 453-459. DOI: https://doi.org/10.29136/mediterranean.592492

Derebaşı E, Bulut G, Col M, Güney F, Nurdoğan Y, Ertürk E. 2014. Physico-chemical and residue analysis of honey from Black Sea region of Turkey. Fresenius Environmental Bulletin, 23(1): 10-17.

Diserens J. 2007. Contaminants and residues in Food. Strategies (if any) to screen and analyze veterinary drug residues in food from animal origin. Proceedings of the 5th International Fresenius Conference Nestle Research Center; Lausanne, Switzerland. http://www.biocop.org/.../ContaminantsResiduesin Food5th Fresenuis ppt.pdf, [Accessed: 15.10.2019]

Draiaia R, Chefrour A, Dainese N, Borin A, Manzinello C, Gallina A, Mutinelli F. 2015. Physicochemical parameters and antibiotics residuals in Algerian honey. African Journal of Biotechnology, 14(14): 1242-1251. DOI: https://doi.org/ 10.5897/AJB2015.14456

Erdoğdu AT, Coşkun Y, Güven İS. 2011. Tüketime sunulan ballarda sülfonamid türevi antibiyotiklerin kalıntılarının belirlenmesi. Bornova Veteriner Bilimleri Dergisi, 33(47): $37-44$. 
EU, 2010. European Union. Commission Regulation (EU) No $37 / 2010$ of 22 December 2009 on pharmacologically active substances and their classification regarding maximum residue limits in foodstuffs of animal origin. Official Journal of the European Union, L15:1-72. https://ec.europa.eu/ health/sites/health/files/files/eudralex/vol-5/reg_2010_37/reg_ 2010_37_en.pdf, [Accessed: 15.10.2019]

Galarini R, Saluti G, Giusepponi D, Rossi R, Moretti S. 2015. Multiclass determination of 27 antibiotics in honey. Food Control, 48: 12-24. DOI: https://doi.org/10.1016/j.foodcont. 2014.03.048

Gölge Ö, Hepsağ F, Kılınççeker O. 2017. Determination of naphthalene levels of honey in eastern mediterranean region. Adyütayam Dergisi, 5(2): 14-23.

Gül A. 2008. Türkiye'de Üretilen Bazı Balların Yapısal Özelliklerinin Gıda Güvenliği Bakımından Araştırılması. Doktora Tezi, Mustafa Kemal Üniversitesi Fen Bilimleri Enstitüsü, Hatay, Türkiye.

Güneş N, Cıbık R, Güneş ME, Aydın L. 2008. Erythromycin residue in honey from the Southern Marmara region of Turkey. Food Additives and Contaminants, 25(11): 13131317. DOI: https://doi.org/10.1080/02652030802233472

Güneş ME, Güneş N, Cibık R. 2009. Oxytetracycline and sulphonamide residues analysis of honey samples from Southern Marmara region in Turkey. Bulgarian Journal of Agricultural Science, 15(2): 163-167.

Johnson S, Jadon N. 2010. Antibiotic residues in honey. Center for Science and Environment, India Habitat Centre, New Delhi. http://cdn.cseindia.org/userfiles/Antiboitics_Honey.pdf, [Accessed:15.10.2019]

Kaftanoğlu O. 2000. III. Arıcılık Kongresi Değerlendirme Raporu. Teknik Arıcılık Dergisi, s.70.

Kaya S. 2000. Antibiyotikler. In: Kaya S, Pirinçci İ, Bilgili A (Editörler). Veteriner Uygulamalı Farmakoloji. Cilt II, Ankara, Türkiye: Medisan Yayınevi. pp 247-420. ISBN: 9757774-39-1

Kaya S. 2018. Hayvansal gıdalarda ilaç kalıntıları ve tüketici sağlığı. International Journal of Scientific and Technological Research, 4(8): 28-37.

Korkmaz SD, Küplülü Ö, Çil Gİ, Akyüz E. 2017. Detection of sulfonamide and tetracycline antibiotic residues in Turkish pine honey. International Journal of Food Properties, 20(S1): S50-S55. DOI: https://doi.org/10.1080/10942912.2017.1288135

Kumar A, Gill JPS, Bedi JS, Chhuneja PK, Kumar A. 2020. Determination of antibiotic residues in Indian honeys and assessment of potential risks to consumers. Journal of Apicultural Research, 59(1): 25-34. DOI: https://doi.org/ 10.1080/00218839.2019.1677000

Kutlu MA, Gül A, Özdemir FA, Kılıç Ö. 2017. Bitlis ili Hizan ilçesinde üretilen ballarda antibiyotik kalıntılarının belirlenmesi. Türk Tarım ve Doğa Bilimleri Dergisi, 4(4): 523-527.

Mahmoudi R, Moosavy M, Norian R, Kazemi S, Nadari MRA, Mardani K. 2014a. Detection of oxytetracycline residues in honey samples using ELISA and HPLC methods. Pharmaceutical Sciences, 19(4): 145-150.

Mahmoudi R, Norian R, Pajohi-Alamoti M. 2014b. Antibiotic residues in Iranian honey by ELISA. International Journal of Food Properties, 17(10): 2367-2373. DOI: https://doi.org/ 10.1080/10942912.2013.809539

Mujic I, Alibabic V, Jokic S, Galijasevic E, Jukic D, Sekulja D, Bajramovic M. 2011. Determination of pesticides, heavy metals, radioactive substances, and antibiotic residues in honey. Polish Journal of Environmental Studies, 20(3): 719724.

Nisha AR. 2008. Antibiotic residues-a global health hazard. Veterinary World, 1(12): 375-377. DOI: 10.5455/vetworld. 2008.375-377
Ortelli D, Edder P, Corvi C. 2004. Analysis of chloramphericol residues in honey by liquid chromatography-tandem mass spectrometry. Chromatographia, 59(1): 61-64. DOI: https://doi.org/ 10.1365/s10337-003-0132-5

Ömür B. 2015. Karadeniz Bölgesinde Üretilen Kestane (Castanea sativa Mill.) Ballarının Biyokimyasal Özelliklerinin İncelenmesi. Yüksek Lisans Tezi, Ordu Üniversitesi Fen Bilimleri Enstitüsü, Ordu, Türkiye.

Özgenç S. 2011. Süt ve Balda Sülfonamidlerin Kromatografik Tayini. Yüksek Lisans Tezi, Dokuz Eylül Üniversitesi Fen Bilimleri Enstitüsü, İzmir, Türkiye.

Özkan O, Eşsiz D, Yazıcı K, Erdağ D. 2015. Ardahan ilinde üretilen ballarda antibiyotik kalıntı düzeylerinin araştırılması. Atatürk Üniversitesi Veteriner Bilimleri Dergisi, 10(2): 8892. DOI: https://doi.org/10.17094/avbd.31906

Özmen N, Alkın E. 2006. Balın antimikrobiyel özellikleri ve insan sağlığı üzerine etkileri. Uludağ Arıc1lık Dergisi, 4: 155-160.

Polat İ. 2011. Güney Marmara Bölgesinde Üretilen Bazı Balların Antimikrobiyal, Antioksidan Aktivitelerinin Pestisid ve Antibiyotik Kalıntılarının İncelenmesi. Yüksek Lisans Tezi, Balıkesir Üniversitesi Sağlık Bilimleri Enstitüsü, Balıkesir, Türkiye.

Rahman KU. 2016. Study of Residual Antibiotics and Their Metabolites in Honey. Doctor of Philosophy in Chemistry, Institute of Chemical Sciences University of Peshawar, Pakistan.

Rao CRM, Kumar LCA, Sekharan CB. 2015. Quantitative analysis of oxytetracycline residues in honey by high performance liquid chromatography. International Research Journal of Biological Sciences, 4(5): 59-65.

Reybroeck W. 2003. Residues of antibiotics and sulphonamides in honey on the Belgian market. Apiacta, 38: 23-30.

Saleh SMK, Mussaed AM, Al-Hariri FM. 2016. Determination of tetracycline and oxytetracycline residues in honey by high performance liquid chromatography. Journal of Agricultural Science and Technology B, 6: 135-139. DOI:10.17265/21616264/2016.02.009

Saridaki-Papakonstadinou M, Andredakis S, Burriel A, Tsachev I. 2006. Determination of tetracycline residues in Greek honey. Trackia Journal of Sciences, 4(1): 33-36.

Saygılı M. 2017. Kırklareli İlinde Arıcılık Faaliyeti Yapan Üreticilerden Toplanan Peteklerde Antibiyotik ve Pestisit Kalıntısı Aranması. Yüksek Lisans Tezi, Namık Kemal Üniversitesi Fen Bilimleri Enstitüsü, Tekirdağ, Türkiye.

Seğmenoğlu MS. 2013. Ballarda streptomisin kalıntı taraması. AVKAE Dergisi, 3(1): 15-17.

SPSS, 2014. IBM SPSS Statistics for Windows, Version 22.00. SPSS Inc., Chicago, IL, USA.

Sunay AE. 2006. Balda antibiyotik kalıntısı sorunu. Uludağ Arıc1lik Dergisi, 6(4): 143-148.

Şireli T. 2013. Süzme Ballarda GC-MS Metodu ile Naftalin Kalıntısının İncelenmesi. Ankara Üniversitesi Bilimsel Araştırmalar Projesi Sonuç Raporu, BAP No: 12H3338002, Ankara, Türkiye.

Taokaenchan N, Sangsrichan S. 2010. HPLC-Fluorescence detection method for quantitative determination of tetracycline antibiotic residues in honey. NU Science Journal, 6 (2): 147-55.

Tayar M, Yarsan E. 2014. Veteriner Halk Sağlığı. Bursa, Türkiye: Dora Yayınevi. ISBN 978-605-4798-63-6.

TGK, 2012. Türk Gıda Kodeksi. Bal Tebliği. Tebliğ No. 58/2012, Resmi Gazete, Tarih: 27 Temmuz 2012, Sayl: 28366, Başbakanlık Basımevi, Ankara, Türkiye. https://www.resmigazete.gov.tr/ eskiler/2012/07/20120727-12.htm, [Accessed: 12.10.2019]

TGK, 2017. Türk Gıda Kodeksi. Hayvansal Gıdalarda Bulunabilecek Farmakolojik Aktif Maddelerin Sinıflandırılması ve Maksimum Kalıntı Limitleri Yönetmeliği. Resmi Gazete, Tarih: 7 Mart 2017, Sayı: 30000, Başbakanlık Basımevi, Ankara, Türkiye. https://www.resmigazete.gov.tr/eskiler/2017/03//201703074.htm, [Accessed: 12.10.2019] 
Toptancı İ. 2013. Çiçek ve Salgı Ballarında Polisiklik Aromatik Hidrokarbon (PAH), Pestisit ve Antibiyotik Kalıntılarının GC/MS ve LC/MS ile Belirlenmesi. Doktora Tezi, Ankara Üniversitesi Fen Bilimleri Enstitüsü, Ankara, Türkiye.

TS, 2002. Türk Standartları Enstitüsü. Bal Standardı. TS 3036, Ankara, Türkiye.

TÜİK, 2017. Türkiye İstatistik Kurumu. Hayvansal Üretim İstatistikleri. 7 Şubat 2017, Sayı: 24655, Ankara, http://www.tuik.gov.tr/HbGetir.do?id=24655\&tb_id=10, [Accessed:12.10.2019]

Uludağ R. 2008. Ege Bölgesinde Tüketime Sunulan Ballarda Sülfonamid Kalıntılarının Araştırılması. Yüksek Lisans Tezi, Adnan Menderes Üniversitesi Sağlık Bilimleri Enstitüsü, Aydın, Türkiye.
Vidal JLM, Aguilera-Luiz MDM, Romero-Gonzalez R, Frenich AG. 2009. Multiclass analysis of antibiotic residues in honey by ultra performance liquid hromatography-andem mass spectrometry. Journal Agricultural and Food Chemistry, 57(5): 1760-1767. DOI: https://doi.org/10.1021/jf8034572

Yarsan E. 2018. Veteriner ilaçları ve ilaçtan kaynaklanan sorunlar. Lalahan Hayvancılık Araştırma Enstitüsü Dergisi, 58(3): 64-68.

Zai IUM, Rehman K, Hussain and Shafqatullah A. 2013. Detection and quantification of antibiotics residues in honey samples by chromatographic techniques. Middle-East Journal of Scientific Research, 14(5): 683-687. DOI: 10.5829/idosi.mejsr.2013.14.5.2114 